\title{
Performance of Pongamia pinnata ROXB. under Waterlogging, Salinity and their Combination in Nursery Environment
}

\author{
Shephali Sachan ${ }^{1}$, Sandeep Kumar², Pooja Kattiparambil ${ }^{3}$ and Anil Kumar ${ }^{4 *}$ \\ ${ }^{1}$ Tropical Forest Research Institute, Jabalpur-482021 (M.P.), India \\ ${ }^{2}$ Forest Research Institute, Dehradun, - 248006 (Uttrakhand), India \\ ${ }^{3}$ Arid Forest Research Institute, Jodhpur- 342005 (Rajasthan), India \\ ${ }^{4}$ ICAR-Indian Agricultural Research Institute, New Delhi-110012, India \\ *Corresponding author
}

\section{Keywords \\ Waterlogging, \\ Salinity, \\ Pongamia pinnata, Parameters, Protein}

\section{Article Info}

Accepted:

22 June 2020

Available Online:

10 July 2020

\section{A B S T R A C T}

The world is facing severe and unpredictable challenges due to increasing abiotic stresses as a consequence of the earth's changing climatic conditions. The increasing waterlogging and salinity stress problems are the example of such disturbances caused in nature. In the present study, the effect of waterlogging, salinity and combined waterlogging \& salinity stress on morphological, physiological and biochemical parameters along with protein profile of Pongamia pinnata at seedling stage under nursery conditions have been discussed. Pot culture experiments were conducted in factorial RBD design to observe the effect of waterlogging (W), salinity (S) and combined salinity \& waterlogging (SW) stress on the selected seedling under nursery conditions for one year. Waterlogging stress condition was created by perforating the polybag at specific height with standard size and watered daily. Salinity was maintained at $8 \mathrm{dS} / \mathrm{m}$ salt concentration. The amount of water equal to the calculated field capacity was provided to each polybag. Total biomass and leaf area were measured in morphological parameters. Physiological parameters viz. photosynthetic rate and stomatal conductance of the seedlings were measured. Total chlorophyll, proline and protein content were estimated for biochemical analysis. Protein profiling of seedlings was performed by SDS-PAGE method. The outcome of the experiment showed that salinity treatment had major negative impact on biomass which can also observe in leaf area. Under waterlogging treatment, the seedling showed very appreciative avoidance and adapted behavior. The seedlings under salt + waterlogging managed to tolerate the combined stress condition which was opposite to deleterious impact of combined abiotic stresses. Two new bands observed under $8 \mathrm{dS} / \mathrm{m} \mathrm{S}+\mathrm{W}$ shows the involvement of protein in the tolerance behavior of seedlings. The plantations of suitable tree species in such areas will be helpful in sustainable forest management and 


\section{Introduction}

The world is facing severe and unpredictable challenges due to increasing abiotic stresses as a consequence of the earth's changing climatic conditions ${ }^{9}$. The increasing waterlogging and salinity stress problems are the example of such disturbances caused in nature.

Waterlogging/flooding stress refers to a condition when water is present in excess amount than its optimum requirement. The soil pores which are previously occupied by oxygen gets filled with excess water causing oxygen deficiency ${ }^{47}$. While, accumulation of dissolved salts in the soil water in a higher amount than required causes salinity problems, inhibiting the plant growth ${ }^{39}$.

Waterlogging induces many alterations in soil physico-chemical properties like $\mathrm{pH}$, redox potential and oxygen level, hence the plants growing on waterlogged soil face the stressful environment in terms of hypoxia (deficiency of $\mathrm{O}_{2}$ ) or anoxia (absence of $\mathrm{O}_{2}$ ) condition ${ }^{5}$. Approximately $10 \%$ of all irrigated farmland comes under frequent waterlogging areas worldwide $^{38}$. The effect of waterlogging in large, flat areas for several days creates the condition of flood causing damage to trees and forests ${ }^{36}$. The waterlogged and marshy lands cover $0.52 \%$ of India's total land area ${ }^{39}$. The districts located in Gangetic Plains, the Brahmaputra Valley, Eastern Coastal plain and in western Rajasthan (Indira Gandhi Canal command area) are under the strong pressure of waterlogging. About 202 districts of the country are affected by waterlogging, the severity of which range between 6-15 per cent in Bihar, Odisha and Assam ${ }^{39}$.

Salinity is also the major abiotic stress which can brutally limit the crop production, especially in arid and semi-arid regions. The substantial increase in soil salinity could affect the long-term health, productivity and survival of trees, and potentially leave discharge sites further degraded ${ }^{28}$. More than 45 million hectares (mha) of irrigated land which accounts to $20 \%$ of total land has been damaged by salt worldwide and $1.5 \mathrm{~m}$ ha is being out of use each year due to high salinity levels in the soil ${ }^{42}$. The salts affect the plants in two ways i.e., osmotic potential and ionic toxicity. Under salt stress, the osmotic potential becomes higher in the soil solution as compare to plant cells as the concentration of salt is high in the surrounding, due to which plants ability to take up water and other essential nutrients gets decline ${ }^{38}$. In India, about 300 million hectares of coastal land is lying barren and uncultivable because of soil affected by salinity ${ }^{13}$. It was estimated that 142 districts distributed in Gujarat, Rajasthan, Punjab, Haryana, Uttar Pradesh, Karnataka, Andhra Pradesh and Tamil Nadu are affected by soil salinity or alkalinity ${ }^{39}$.

About 60-80 million hectares of land is affected to some extent by combined salinity and waterlogging stress ${ }^{17}$. In the irrigated areas of semi-arid regions, especially in northwest India, a considerable recharge to the groundwater leads to waterlogging and secondary salinization. Soil salinization is the process of accumulation of excess salts in the root zone creating osmotic stress, which results into physiological drought stress combining with ionic toxicity, whereas waterlogging is the presence of excess water in the root zone of plants resulting in poor gas exchange and eventually anaerobic conditions. Because waterlogging or salinity alone is harmful to the growth of most dryland species, their combined effects would be expected to be especially damaging ${ }^{32}$.

The selected species Pongamia pinnata (Family - Fabaceae), popularly known as Karanj, is a medium size shade tree species ${ }^{30}$ widely distributed in the Indian subcontinent, 
south-east Asia, Fiji, Myanmar, northern Australia, the East-African coast, southern China and the Seychelles Islands.

In India, this tree is distributed throughout the country except for temperate regions and is considered to be native to the western ghats of India $^{12}$. It is a preferred nitrogen-fixing species for controlling soil erosion and binding sand dunes because of its dense network of lateral roots ${ }^{4}$ and phytoremediation quality ${ }^{30}$. The species is famous for its seed oil which has biodiesel potential, many industrial and medicinal applications ${ }^{4}$.

The present study focuses on the species morphological, physiological, biochemical and molecular response against artificially applied waterlogging, salinity and combined waterlogging + salt stress conditions. The study will be very helpful to know the potential of Pongamia pinnata species against the selected abiotic stresses in the nursery environment.

\section{Materials and Methods}

\section{Experimental site and plant material}

Pot culture experiments were conducted in the nursery of Tropical Forest Research Institute (TFRI), Jabalpur (M.P.) for one year.

The location of experimental site in the nursery was specified as $23^{0} 5,57.2$ " $\mathrm{N}$ latitude, 79059'2" E longitude and $394 \mathrm{~m}$ altitude above the sea level according to Global Positioning System (GPS). Pongamia pinnata (Karanj) tree species was selected for the study. The seeds were collected from TFRI campus during March to May and sown in the nursery beds in June, just before first shower of rainfall, which is favourable for normal and healthy germination process.

\section{Growth condition and experimental design}

The size of nursery mother beds was fixed to be $10 \mathrm{~m} \mathrm{x} 1 \mathrm{~m}$ and the sowing medium was sand which provided sterile conditions for germination of seeds. Germination period for the Pongamia pinnata was observed to be 5-7 days. After the germination of seeds, the seedlings having 2-3 leaves were transferred to transparent polythene bags of standard size $(15 \mathrm{~cm} \times 23 \mathrm{~cm})$ filled with soil, sand and farm yard manure (FYM) in 2:1:1 ratio. The polythene bags were initially placed under shade for one month to protect the seedlings from direct sunlight and then kept in open area for another one month in order to acclimatize them with the prevailing conditions.

Factorial Randomized Block Design (RBD) was adopted to conduct pot culture experiments in order to observe the effects of waterlogging, salinity and their combination stress.

After acclimatizing seedlings in polythene bags for a month in open areas, three treatments (W- Waterlogging, S - Salinity and SW - Salinity and Waterlogging) were provided to the seedlings including control (C). Each treatment consisted of nine seedlings and the experiment was replicated thrice.

\section{Waterlogging treatment}

Waterlogging experiments in the seedlings planted in polybags under nursery condition were conducted according to the experimental design mentioned above. The amount of water equal to the field capacity, $24.86 \%$ [Soil moisture at field capacity $(\%)=(\mathrm{WW}-\mathrm{DW}) \mathrm{x}$ 100/DW, where, WW - Wet Weight of soil + plant (g) and DW - Dry Weight of soil + plant (g), adopted by Tyree ${ }^{52}$ et al., (2002)] was given to each polybags. 
Artificial waterlogging conditions were created by making 8 holes of size $6 \pm 0.5 \mathrm{~mm}$ in each polybag through punching machine in the periphery of the polybags below $3 \mathrm{~cm}$ from surface ${ }^{33}$. The polybags were watered daily with the amount equal to the field capacity $^{21,14}$. In the control plants, the holes were made at the bottom of polybags and watered at the interval of 2-4 days. This way no waterlogging was observed in control plants as the excess water drained out of the holes from the bottom ${ }^{25}$. Moreover, waterlogging was attained in polybags perforated at $3 \mathrm{~cm}$ from the surface.

\section{Salinity treatment}

Salinity was artificially created in the polybags through supply of salt $(\mathrm{NaCl})$ dissolved water, which was maintained to be $8 \mathrm{dS} / \mathrm{m}$ after regularly measuring the electrical conductivity of the soil ${ }^{44}$.

\section{Salinity and waterlogging combined treatment}

Combined salinity and waterlogging conditions were artificially created by adding $\mathrm{NaCl}$ equal to $8 \mathrm{dS} / \mathrm{m}$ through irrigated water to polybags equivalent to the calculated field capacity daily.

\section{Morphological parameters}

Total biomass of each seedlings was estimated by destructive method at the end of experiment. Mature leaves were plucked and size was measured using Systronics make Leaf Area Meter at the end of experiment. Three leaves were considered per treatment and replicated thrice. The average readings were considered for statistical analysis.

\section{Physiological parameters}

Physiological parameters viz. photosynthetic rate and stomatal conductance of the seedlings of selected species were measured at the end of one year between 8:00 AM to 10:00 AM using CID-340 make Photosynthetic System. During measurement of physiological parameters, the Photosynthetically Active Radiation (PAR) ranged from $803-2298 \mu \mathrm{mol} / \mathrm{m}^{\wedge} 2 / \mathrm{s}$ were also noted. Calibration of the instrument was done before use. After switching on the instrument and feeding required parameters, it was kept for 30 minutes for stabilization. Mature leaves were placed in the leaf chamber of the instrument. Three leaves taken per treatment and replicated thrice ${ }^{26}$.

\section{Biochemical parameters}

Biochemical parameters like chlorophyll, proline and protein content were estimated at the end of experiment. Chlorophyll was estimated following Arnon's ${ }^{3}$ method (1949). Weighed $0.1 \mathrm{~g}$ of fresh leaf sample, finely cut and well crushed to fine pulp in pestle mortar with the addition of $5 \mathrm{ml}$ of $80 \%$ acetone. Centrifuged at $5000 \mathrm{rpm}$ for $5 \mathrm{~min}$ and transferred the supernatant in a test tube. Vortexed the residue with the addition of $5 \mathrm{ml}$ of $80 \%$ acetone and again centrifuged it for 5 min in $5000 \mathrm{rpm}$. The supernatant was collected in the same test tube. Mixed and read the absorbance of the solution at 645 , 663 and $470 \mathrm{~nm}$ against the solvent $(80 \%$ acetone) blank.

\section{Calculation}

The amount of extracted chlorophyll was calculated in the $\mathrm{mg}$ chlorophyll/g tissue by following formula:

Chlorophyll a $(\mathrm{mg}$ g-1) $=[(12.7 \times$ A663) $(2.6 \times \mathrm{A} 645)] \times \mathrm{V} / 1000 \times \mathrm{W}$

Chlorophyll b $(\mathrm{mg}$ g-1) $=[(22.9 \times$ A645 $)-$ $(4.68 \times \mathrm{A} 663)] \times \mathrm{V} / 1000 \times \mathrm{W}$ 
Total Chlorophyll $=[(20.2 \times$ A645 $)+(8.02 \times$ A663) $\times$ V/1000 x W

Proline content in the leaves was quantified by the spectrophotometric method followed by Bates ${ }^{8}$ et al., (1973). Extract $0.1 \mathrm{~g}$ of dried leaf sample by homogenizing in $5 \mathrm{ml}$ of $3 \%$ aqueous sulphosalicyclic acid. Centrifuged at $3000 \mathrm{rpm}$ for $25 \mathrm{~min}$ and homogenate was filtered through Whatman No. 2 filter paper. 2 $\mathrm{ml}$ of filterate, glacial acetic acid and acid ninhydrin were taken in a test tube and heated it in the boiling water bath for 1 hour. Terminated the reaction by placing the tube in ice bath. Added $4 \mathrm{ml}$ toluene to the reaction mixture and stirred well for 20-30 seconds. Separated the toluene layer and warmed to room temperature. Measured the red colour intensity at $520 \mathrm{~nm}$. Ran a series of standard with pure proline in a similar way and prepare a standard curve. Toluene was taken as a blank for both sample and standard. Found out the amount of proline in the test sample from the standard curve.

\section{Calculation}

The proline content was expressed as follows:

$\mu$ moles per g tissue $=$

\begin{tabular}{cc}
$\mu \mathrm{g}$ proline/ml x ml toluene & 5 \\
\hline$-\mathbf{y}^{-}$ & $\mathrm{g}$ sample
\end{tabular}

Where, 115.5 is the molecular weight of proline.

Protein content was estimated by spectrophotometric method followed by Bradford $^{10}$ (1976). $50 \mu \mathrm{g}$ of fresh leaf sample was thoroughly grounded to a fine powder in a pre-chilled mortar by liquid nitrogen and then mixed with $5 \mathrm{ml}$ lysis buffer (1.0M Tris Base buffer of $\mathrm{pH} 8.0$ containing $25 \mathrm{mM}$ EDTA, $10 \mathrm{mM} \beta$-mercaptoethanol and $1 \%$
PVP). Centrifuged it for $10 \mathrm{~min}$ in $13000 \mathrm{rpm}$ in $4^{\circ} \mathrm{C}$. Supernatant was used for analysis. 100 $\mu l$ supernatant taken in a test tube. Prepared standard curve of concentration 10 to $100 \mu \mathrm{l}$ working standard. Both samples and standards were prepared in duplicates. $100 \mu \mathrm{l}$ of distilled water was taken into a tube to provide the reagent blank. Made the volume $300 \mu \mathrm{l}$ in all test tubes with distilled water. Added $3 \mathrm{ml}$ of dye to each tubes and mixed well by shaking manually. Kept the test tubes in dark for 15-30 minutes. Measured the absorbance at $595 \mathrm{~nm}$. The concentration of protein in the samples were calculated through standard curve.

\section{Protein profile}

Protein profiling of fresh leaves was done after one year experiment by 'Laemmli ${ }^{31}$ Method' using Sodium Dodecyl Sulphate Polyacrylamide Gel Electrophoresis (SDS PAGE). The protein of fresh leaves was isolated by following Bradford's method and then proceeded for profiling.

\section{Reagents required}

Acrylamide/Bis-acrylamide solution (30\% stock) $-30 \mathrm{~g}$ acrylamide and $0.8 \mathrm{~g}$ bisacrylamide was dissolved in $60 \mathrm{ml}$ distilled water and made the volume upto $100 \mathrm{ml}$. Stored at $4^{0} \mathrm{C}$.

Ammonium Persulphate (10\%) - $10 \mathrm{~g}$ ammonium persulphate was dissolved in $100 \mathrm{ml}$ distilled water and stored as 1 $\mathrm{ml}$ aliquots in microcentrifuge tubes at $20^{\circ} \mathrm{C}$.

Tetramethylethylenediamine (TEMED)

SDS (10\%) - $10 \mathrm{~g}$ SDS was dissolved in 100 $\mathrm{ml}$ distilled water, heated till bubbles emerge and stored at RT.

Separating gel Buffer $(0.98 \mathrm{M}, \mathrm{pH}$ 8.8) $11.87 \mathrm{~g}$ Tris Base was dissolved in 100 $\mathrm{ml}$ distilled water. Adjust the $\mathrm{pH}$ to 8.8 .

Stacking gel Buffer (0.325M, pH 6.8) - 3.94 
g Tris Base was dissolved in $100 \mathrm{ml}$ distilled water. Adjust the $\mathrm{pH}$ to 6.8 .

Electrode/Tank Buffer $(10 \mathrm{X})-$

Tris Base $(50 \mathrm{mM})-18.15 \mathrm{~g}$

Glycine $(384 \mathrm{mM})-86.25 \mathrm{~g}$

SDS $(0.1 \%)-3 \mathrm{~g}$

Made the volume upto $3000 \mathrm{ml}$ and heated on hot plate till bubbles appear, cool and store at RT.

Destaining solution I (DS I - $1000 \mathrm{ml}$ )

Methanol $-500 \mathrm{ml}$
Glacial Acetic Acid - $100 \mathrm{ml}$

Distilled water $-400 \mathrm{ml}$

Destaining solution II (DS II - $1000 \mathrm{ml}$ ) -

Methanol - $300 \mathrm{ml}$

Glacial Acetic Acid - $100 \mathrm{ml}$

Distilled water $-600 \mathrm{ml}$

Staining solution $(1000 \mathrm{ml})-$

Coomassie Brilliant Blue (R250) - $2.0 \mathrm{~g}$

Methanol - $400 \mathrm{ml}$

Glacial Acetic Acid - $200 \mathrm{ml}$

Distilled water $-400 \mathrm{ml}$

Table.1 Composition of Separating gel (12\%)

\begin{tabular}{|l|c|}
\hline \multicolumn{1}{|c|}{ Composition } & $\mathbf{2 4 . 4 6} \mathbf{~ m l}$ \\
\hline 30\% Acrylamide/Bis - acrylamide & $9.6 \mathrm{ml}$ \\
\hline Separating Buffer (pH 8.8) & $12 \mathrm{ml}$ \\
\hline Distilled water & $2.4 \mathrm{ml}$ \\
\hline SDS (10\%) & $240 \mu \mathrm{l}$ \\
\hline TEMED & $20 \mu \mathrm{l}$ \\
\hline Ammonium Persulphate (10\%) & $200 \mu \mathrm{l}$ \\
\hline
\end{tabular}

Composition of Stacking gel (5\%)

\begin{tabular}{|l|c|}
\hline \multicolumn{1}{|c|}{ Composition } & $\mathbf{7 . 5 0} \mathbf{~ m l}$ \\
\hline 30\% Acrylamide/Bis - acrylamide & $2.0 \mathrm{ml}$ \\
\hline Stacking Buffer (pH 6.8) & $3.2 \mathrm{ml}$ \\
\hline Distilled water & $2.12 \mathrm{ml}$ \\
\hline SDS (10\%) & $66 \mu l$ \\
\hline TEMED & $10 \mu \mathrm{l}$ \\
\hline Ammonium Persulphate (10\%) & $100 \mu \mathrm{l}$ \\
\hline
\end{tabular}

Composition of Sample buffer (pH 6.8)

\begin{tabular}{|l|c|}
\hline \multicolumn{1}{|c|}{ Composition } & $\mathbf{1 0 0} \mathbf{~ m l}$ \\
\hline Tris Base (625 mM) & $7.57 \mathrm{~g}$ \\
\hline SDS (2\%) & $2 \mathrm{~g}$ \\
\hline Glycerol (10\%) & $10 \mathrm{ml}$ \\
\hline 及-mercaptoethanol (5\%) & $5 \mathrm{ml}$ \\
\hline Bromophenol blue (0.001\%) & $0.001 \mathrm{~g}$ \\
\hline
\end{tabular}

\section{Procedure}

Assembled the components SCIE-PLAS

TV400Y SDS - PAGE unit: tall glass plate, notched glass plate, $1 \mathrm{~mm}$ spacers, gel casting frame, gel casting stand, teflon comb, electrophoresis chamber, electrode wires and voltage 
unit.

The glass plates were assembled using clamps and $1 \mathrm{~mm}$ spacers.

The solution for $12 \%$ separating gel was prepared and poured between glass plates using a gradient mixer with constant stirring, leaving a gap of 3.5 $\mathrm{cm}$ from the top. Polymerization of gel took place 20-30 minutes.

Now after separating gel polymerization, teflon comb was inserted and 5\% stacking gel was prepared. The gel was poured carefully into cavity from sides using micropipette to prevent formation of bubbles till top of the notched plate. Polymerization of gel took place 10-15 minutes.

Meanwhile prepared the loading dye, for running standard (Bovine serum albumin/protein ladder - Low range protein marker, 3-40 $\mathrm{kDa}$ and Mid range protein marker, $14-80 \mathrm{kDa}$ ) took sample buffer and standard in 1:1 ratio (10 $\mu 1$ each). For running sample whatever the concentration was got from spectrophotometer readings for $100 \mu 1$ is taken in 1:1 ratio with sample buffer.

The standard and samples loading dye were then kept for $10 \mathrm{~min}$ in $100^{\circ} \mathrm{C}$ in water bath. After warming cooled down at room temperature and ready for loading.

After polymerization of stacking gel, the comb was removed carefully out of the stacking gel.

The sandwich assembly (glass plates with frame) seperated from gel casting stand and inserted in the electrophoresis chamber.

The electrode running buffer was poured in the chamber upto the top of the glass plates such that wells and thin electrode wires were fully covered.

A pre run was carried out at $60 \mathrm{~V}$ for $15-30$ minutes to flush all ions out from the wells to decrease interference with sample run.

Now $20 \mu$ l of loading dye of each (standard and samples) were loaded into wells carefully with the help of micropipette.

Plugged in the electrodes red to red and black to black on voltage unit and electrophoresis chamber. The electrophoresis was carried out at $110 \mathrm{~V}$ during stacking and continued at $220 \mathrm{~V}$ for 8-9 hours till the dye front reached the bottom of the gel.

After completion of the gel run the sandwich assembly was removed from the electrophoresis unit.

The buffer in the assembly was discarded and the glass plates were separated using plastic spatula after removal of spacers in the tray full of distilled water. The gel got separated.

The gel was then transferred to DS I and kept for overnight with gentle shaking.

After discarding DS I, the gel was incubated in staining solution of Coomassie Brilliant Blue for 20 minutes with gentle shaking on shaker platform.

After staining, the excess stain from the container was collected for future use and the gels as well as the container were rinsed with small quantity of DS II followed by further incubation in fresh DS II for few hours to effectively destain the gel.

The washing step in DS II was continued till the gel became clear of any background stain.

The protein bands appeared after DS II in the gel was properly scanned by Gene Sys scanner.

The molecular weight of the sample band protein were determined by Gel Analyzer software.

\section{Statistical analysis}

Analysis of Variance (ANOVA) and 
significant variation among different treatments was observed by comparing calculated $F$ values with tabulated $F$ values. Interactions among different treatments were also calculated using factorial RBD design. Pairwise comparison among the selected treatments was done after calculating critical difference $(C D)$ at $5 \%$ significance levels.

\section{Results and Discussion}

\section{Morphological parameters}

Significant $(\mathrm{P}<0.05)$ difference in total biomass and leaf area was observed in $P$. pinnata tree species seedlings under control, waterlogging, salinity and combined salinity and waterlogging treatments at the end of experiment (Table 1).

The total biomass was found to be maximum (16.03 g) under waterlogging and minimum $(1.89 \mathrm{~g})$ under salinity treatment respectively. Leaf area of $P$. pinnata leaves was found maximum $\left(43.57 \mathrm{~cm}^{2}\right)$ under waterlogging and minimum $\left(11.80 \mathrm{~cm}^{2}\right)$ under control treatment. The leaves were very tiny for measurement under salinity treatment (Fig. 1).

\section{Physiological parameters}

Significant $\quad(\mathrm{P}<0.05) \quad$ difference in photosynthetic rate and stomatal conductance was observed in $P$. pinnata tree species seedlings under control, waterlogging, salinity and combined salinity and waterlogging treatments at the end of experiment (Table 1).

The photosynthetic rate and stomatal conductance were found maximum (3.07 $\mu \mathrm{mol} / \mathrm{m}^{\wedge} 2 / \mathrm{s}$ and $36.31 \mathrm{mmol} / \mathrm{m}^{\wedge} 2 / \mathrm{s}$ ) under waterlogging and minimum $\left(1.22 \mu \mathrm{mol} / \mathrm{m}^{\wedge} 2 / \mathrm{s}\right.$ and $3.36 \mathrm{mmol} / \mathrm{m}^{\wedge} 2 / \mathrm{s}$ ) under salinity + waterlogging treatment respectively. The leaves were very small and rare, unfit for leaf chamber for measuring physiological parameters under salinity treatment (Fig. 2).

\section{Biochemical parameters}

Significant $(\mathrm{P}<0.05)$ difference in proline and protein content was observed while non significant $(\mathrm{P}>0.05)$ difference in total chlorophyll content was obtained in $P$. pinnata tree species seedlings under control, waterlogging, salinity and combined salinity and waterlogging treatments at the end of experiment (Table 1).

The total chlorophyll was found maximum (33\%) under control and waterlogging treatment equally while minimum (15\%) under salinity + waterlogging treatment respectively. Proline was found maximum $(55 \%)$ under salinity + waterlogging treatment while minimum $(3 \%)$ under control treatment seedlings respectively. Protein was found maximum $(46 \%)$ in control treatment and decreased under stress treated seedlings. The minimum protein $(13 \%)$ was observed under salinity treated seedlings (Fig. 3).

\section{Protein profiling}

In $P$. pinnata, nine bands were showed by control at 77.70, 54.43, 42.34, 36.91, 30.41, 23.94, 18.92 and 17.41 kDa. No bands were observed in individual waterlogging and salinity experiment. In $8 \mathrm{dS} / \mathrm{m}+\mathrm{SW}$ two new bands were observed at 47.26 and $32.84 \mathrm{kDa}$ along with other bands. The intensity of bands were high in control followed by $8 \mathrm{dS} / \mathrm{m}+$ SW (Fig. 4).

\section{Morphological parameters}

The $P$. pinnata seedlings shown maximum biomass and leaf area under waterlogging treatment which may be due to the development of some morphological changes like formation of adventitious roots, initiation of hypertrophied lenticels and establishment of aerenchyma ${ }^{5}$. Wang ${ }^{54}$ et al., (2016) suggested that under waterlogging and 
flooding, the tree species with strong waterlogging tolerance have higher ability to maintain energy-metabolic balance and their growth can be maintained at certain level. Also, increased leaf size could be the strategy to drain more water from the bottom, facilitating higher transpiration from the leaves. This way more water is removed from the soil ${ }^{1,29}$. The broader leaf size accumulates more and more carbon which increases plant biomass ${ }^{5}$. Shukor ${ }^{46}$ et al., (2014) also observed increase in height and biomass in Azadirachta excelsa under artificial waterlogging treatment for limited period. The insignificant reduction in the growth attributes of Hopea odorata Roxb. tree species under waterlogging treatments, proved to be as tolerant species against short and long-term waterlogging ${ }^{1}$. $\mathrm{Su}^{49}$ et al., (2011) found higher biomass in transgenic poplar trees under waterlogging stress.

Table.1 Critical difference and standard error $( \pm)$ values of the selected parameters

\begin{tabular}{|l|c|c|}
\hline \multicolumn{1}{|c|}{ Parameters } & Critical Difference (CD) & Standard Error (SE \pm ) \\
\hline Total biomass & 1.994 & 0.799 \\
\hline Leaf area & 5.796 & 2.324 \\
\hline Photosynthetic rate & 0.149 & 0.060 \\
\hline Stomatal conductance & 1.617 & 0.648 \\
\hline Total chlorophyll & NS* & 0.461 \\
\hline Proline & 21.033 & 8.432 \\
\hline Protein & 0.565 & 0.227 \\
\hline
\end{tabular}

*NS = non-significant

Fig.1 Effect of waterlogging, salinity and combined salinity and waterlogging stress on total biomass and leaf area of Pongamia pinnata seedlings

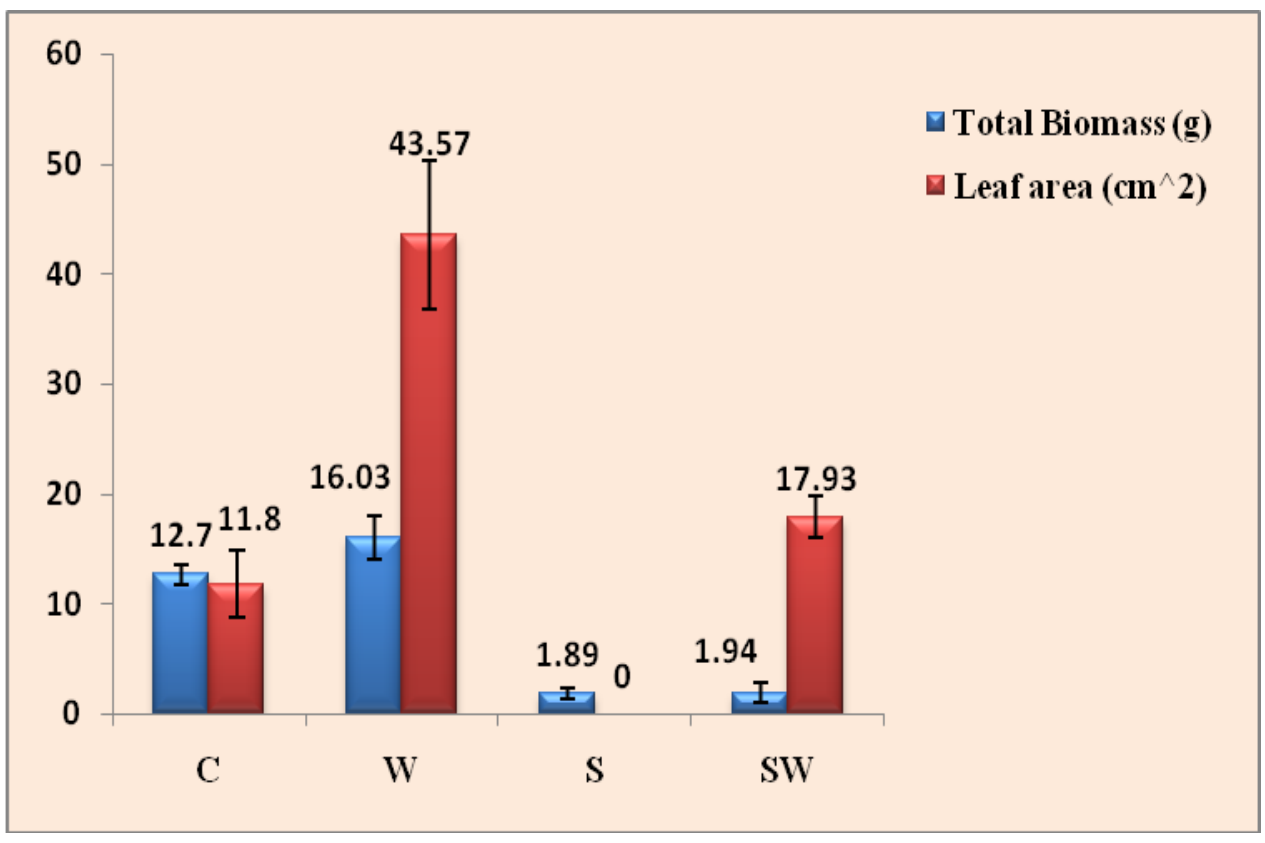


Fig.2 Effect of waterlogging, salinity and combined salinity and waterlogging stress on photosynthetic rate (Pn) and stomatal conductance (C) of Pongamia pinnata seedlings

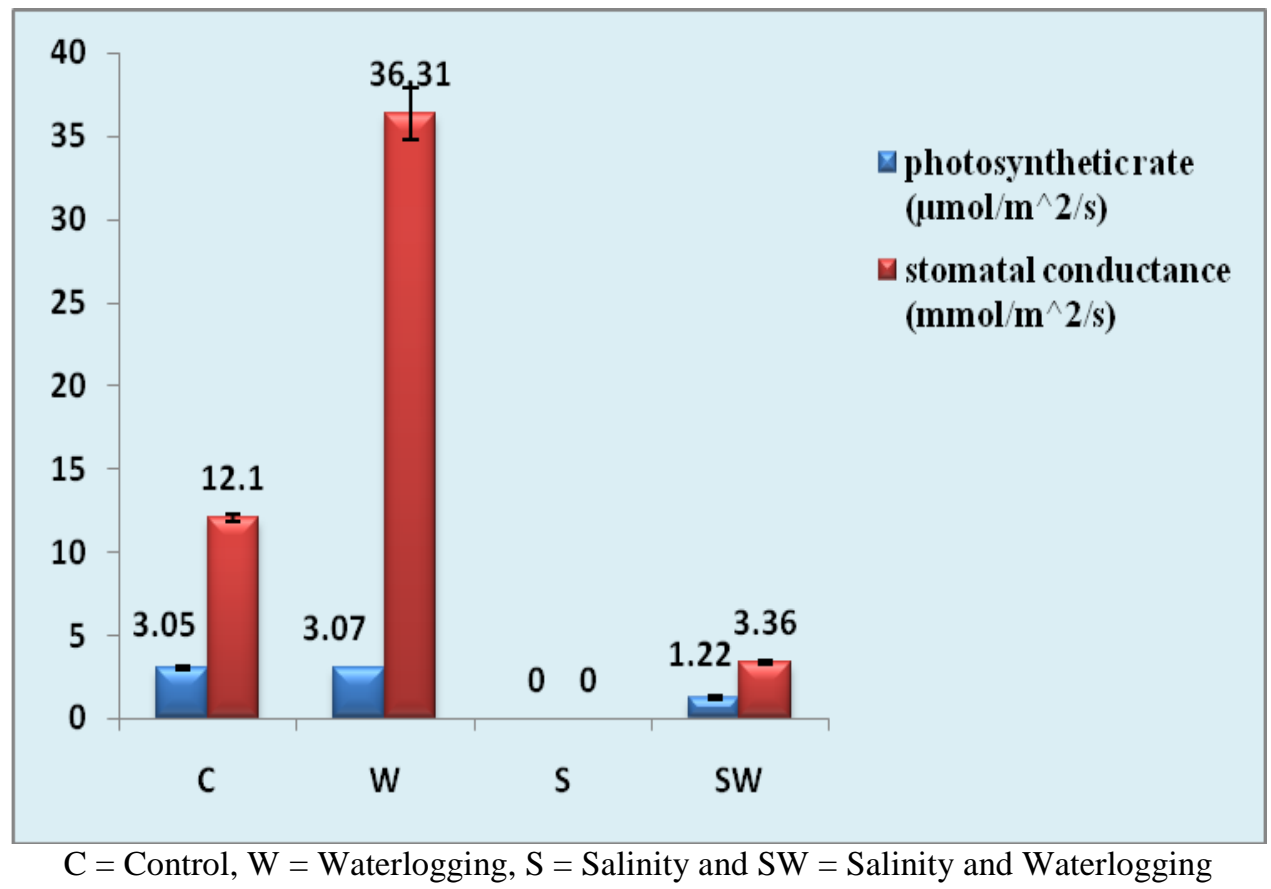

Fig.3 Effect of waterlogging, salinity and combined salinity and waterlogging stress on total chlorophyll and proline of Pongamia pinnata seedlings

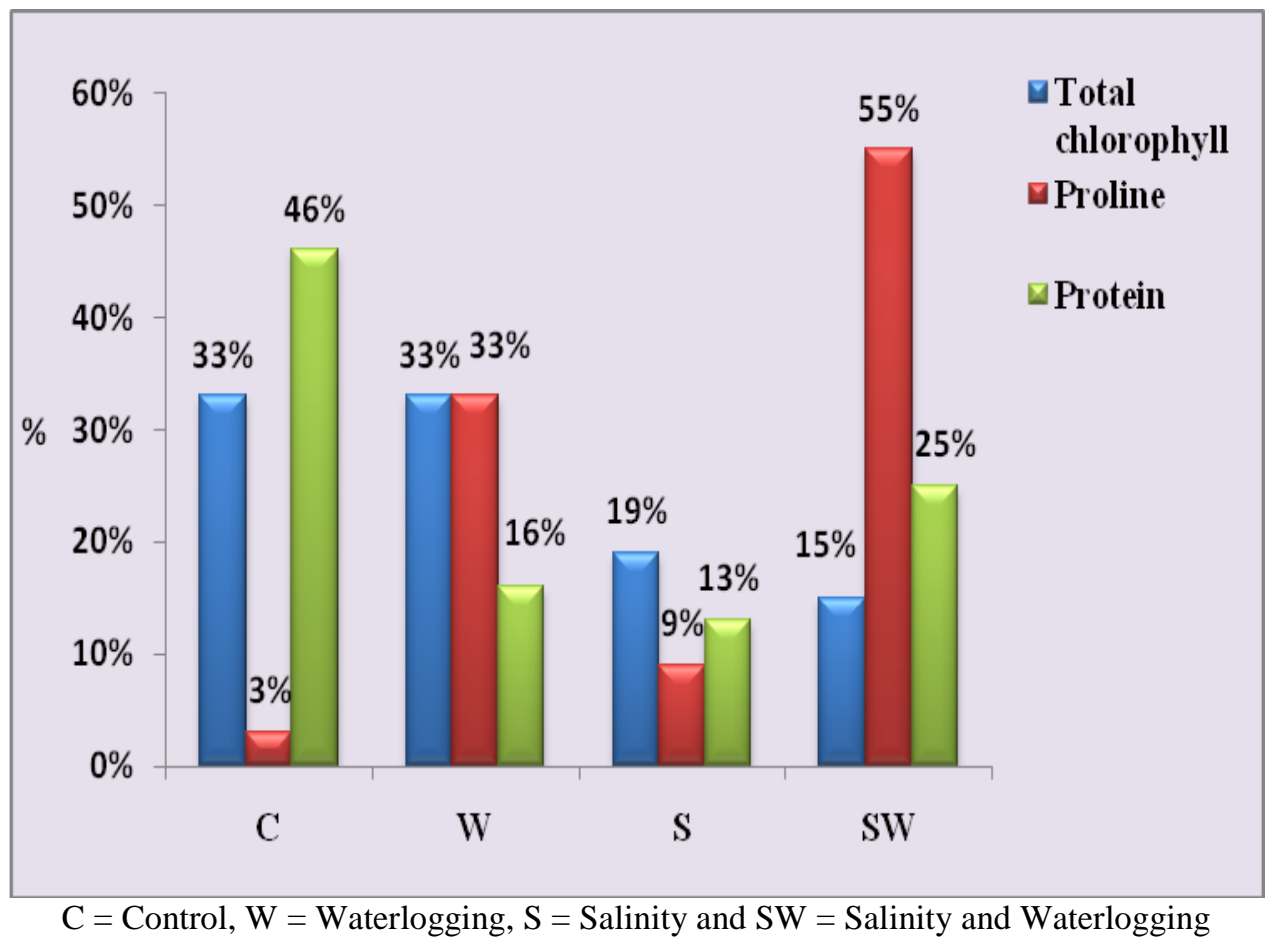


Fig.4 P . pinnata protein profile. PM - Protein Marker (14-80 kDa), PC - Control, P1 Waterlogging, P2 - 8 dS/m Salinity, P3 - 8 dS/m Salinity + Waterlogging

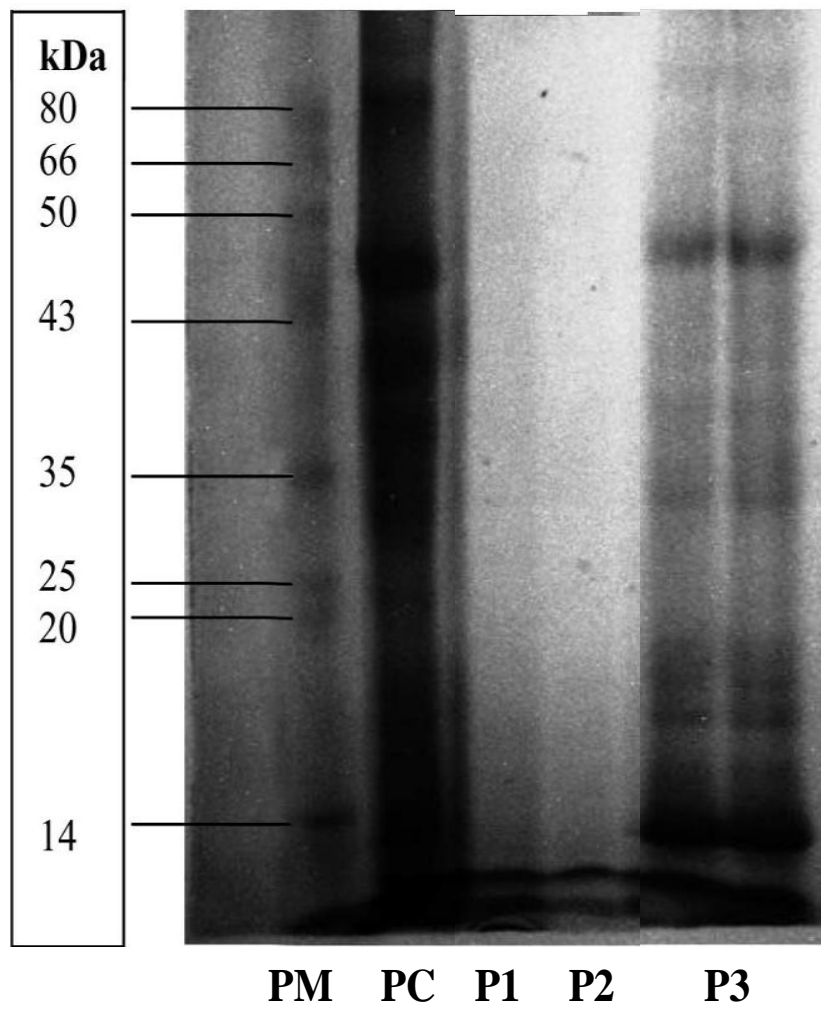

Total biomass declined with severity of salinity stress. The decrease in biomass is the negative impact of salt due to the increased ionic toxicity and higher osmotic potential ${ }^{37}$. Singh $^{47}$ (1999) also observed higher fresh weight and dry biomass in control for $P$. pinnata seedlings, which decreases with increase in salinity. The presence of rare and small leaves unfit for measurement corroborates with Abdul Qados ${ }^{2}$ (2011) studies who reported that low concentration of salinity do not show any significant effect, but increase in salt concentration shows deleterious effect on leaf number and size in plant species. The accumulation of $\mathrm{NaCl}$ in the cell walls and cytoplasm of the leaves reduces leaf number as the vacuole sap accumulate more salt than required resulting into increase in salt (ionic) concentration leading to their quick death and shedding ${ }^{37}$.
The waterlogging and salinity alone is harmful, their combination effects would be expected to be especially damaging ${ }^{32}$. Similar results were also noted by $\operatorname{Singh}^{48}$ et al., (1996) in D. latifolia, which when exposed to various managed water salinity concentrations of $0.3,0.6$ and $0.9 \mathrm{ds} \mathrm{m}^{-1}$, the Above Ground Biomass (AGB) reduced to 29, 50 and 63\% respectively. Salinity $(12 \mathrm{dS} / \mathrm{m})$ and hypoxia alone as well as in combination caused a significant reduction in shoot biomass of wheat $^{45}$. The slight increase in biomass as compare to individual salinity stress might be due to persistence of leaves till the end of experiment. Against the deleterious effect, the increased leaf size as compare to control could be due to morphological adaptation feature of development of lateral roots more than main tap root, also reported by Gibberd ${ }^{21}$ et al., (2001) and Arpiwi ${ }^{4}$ (2013) or due to the 
phenomena of transporting the excess salt to the vacuole or older tissues thereby protecting the plant from salinity stress ${ }^{24}$.

\section{Physiological parameters}

The photosynthetic rate and stomatal conductance were found maximum under waterlogging treatment. Jackson and Colmer ${ }^{27}$ (2005), observed that certain species are highly productive in waterlogged areas due to some physiological adaptations. The photosynthetic rate and biomass content were found positively and significantly correlated with each other depicting that higher photosynthetic rate accumulates more biomass in the seedlings. Higher photosynthetic rate and stomatal conductance accumulated more biomass by maximising the loss of water through stomatal opening (transpiration), because water is abundantly available under waterlogged conditions.

The presence of rare and tiny leaves shows unability to produce under the salinity treatment till the end of one year of experimentation. Freitas ${ }^{20}$ et al., (2017) also observed that Tectona grandis in the early stages of development is highly sensitive to salinity stress, slowing down the vegetative growth.

The combination of waterlogging with ionic toxicity caused by salt stress, thus create more drastic situation for plants to survive. Combination of salinity and waterlogging leads to land salinization by transporting salts to the surface and affecting rate of photosynthesis and stomatal conductance in plants $^{18,}$ 19, 15. Tounekti $^{51}$ et al., (2018) reported that combined stresses decreases stomatal density, gas exchanges due to stomatal closure and inhibits photosynthesis processes. The findings are in line with $\mathrm{Azizi}^{7}$ et al., (2017), who reported that high concentration of flooding and salinity water leads to strong reductions in photosynthesis and stomatal conductance in Populus euphratica.

\section{Biochemical parameters}

Chlorophyll content in the leaves of the selected tree species was found nonsignificant under the various treatments but was found maximum under waterlogging treatment as the content is related with photosynthetic rate. The results are in agreement with the studies conducted by Gratani $^{23}$ et al., (1998) in Quercus ilex L species who found the positive correlation between chlorophyll content and photosynthetic rate. The chlorophyll followed decreasing trend then from control = waterlogging, salinity to their combination treatment. Parida ${ }^{40}$ et al., (2004) described that $\mathrm{NaCl}$ has limiting effect on photochemistry, that ultimately affects photosynthesis by inhibiting chlorophyll synthesis. Salinity reduces chlorophyll 'a' chlorophyll ' $b$ ' and total chlorophyll contents in agricultural crops ${ }^{2}$. The interaction of salinity and waterlogging has reduced total chlorophyll content in tree seedlings, which corroborates several studies conducted by different authors ${ }^{18,19,15}$.

The activation of protective system against the generation of reactive oxygen species (ROS) leads to production of number of enzymatic and non-enzymatic antioxidant species $^{13}$. Highest proline content under combination treatment in the present study, supports other studies conducted by Matysik ${ }^{34}$ et al., (2002) in Linum usitatissimum; Tounekti ${ }^{51}$ et al., (2018) in Salvadora persica and Carter $^{11}$ et al., (2006) in Casuarina obesa. Increase in proline content under saline-waterlogged conditions can be attributed to the regulation of foliar $\mathrm{Na}^{+}, \mathrm{Cl}^{-}$ and $\mathrm{K}^{+}$concentrations ${ }^{37}$ due to which the seedlings managed to respond better than expected from combination of two deleterious abiotic stresses. The upright morphological 
and physiological attributes of $P$. pinnata seedlings under waterlogging treatment as compared to control could also involve the role of proline which is second highest here. Increase in proline under stress protects the plant from free-radical induced injury and helps in stabilizing protein and DNA repair thus protecting from oxidative stresses ${ }^{13}$. Parvin and Karmoker ${ }^{41}$ (2013) also observed increase in proline content under waterlogging stress in Corchorus capsularis. The role of protective enzymatic and nonenzymatic compounds become ineffective when the stress persistence for longer time as there is rise in reactive oxygen species which also leads to destruction in the protective system of plant. This might have happened under salinity treatment.

The protein content was observed at its peak in control treatment and then found to be decreased in the selected abiotic stress treatments. The number of common negative changes observed in a plant cell due to abiotic stress generated unfavourable environment like generation of reactive oxygen species (ROS), downregulation and switch off of certain proteins and destruction and damage of cellular components, as a result of which the total protein amount goes down ${ }^{55}$. Parvin and Karmoker ${ }^{41}$ (2013) observed decrease in protein content under waterlogging stress in Corchorus capsularis. The lowest amount of protein content under salinity treatment shows the lethal impact of sodium chloride accumulation. Salt stress induces an accumulation of superoxide radicals $\left(\mathrm{O}_{2}\right)$ and hydrogen peroxide $\left(\mathrm{H}_{2} \mathrm{O}_{2}\right)$ in different cell compartments, including chloroplasts, mitochondria and apoplastic space, which correlates with increases in some oxidative stress parameters, such as lipid peroxidation and protein oxidation ${ }^{22,}{ }^{35}$. Protein concentration significantly decreased with the increase in salt levels in Paulownia imperialis and $P$. fortune $i$ trees compared to controls in which no sodium chloride was added. He concluded that decrease in protein contents is mainly due to loss of $\mathrm{K}+$ ion under salinity stress, which helps in synthesis ${ }^{6}$. During the course of the experiment the salinity and waterlogged stress seedlings showed slight increase in protein content as compare to individual stresses which may be due to synthesis of some different proteins in response to stress ${ }^{16}$ which can be seen in the results of protein profiling.

\section{Protein profiling}

The control proteins observed in $8 \mathrm{dS} / \mathrm{m}+$ SW combination along with two new protein bands. Although, morphological and physiological response were found to be superior in waterlogging experiment than $8 \mathrm{dS} / \mathrm{m}$ salinity and their combinations, it might be possible in first that control proteins were no longer required and its production became suppressed and in later these proteins required in order to manage the severity. The combination treatment seems to be showed some positive effect as compared to individual stresses which shows plant protective measure for maintaining resistivity in $8 \mathrm{dS} / \mathrm{m}+\mathrm{SW}$. The response of plants to combinations of two or more stress conditions is unique and cannot be directly extrapolated from the response of plants to each of the different stresses applied individually. Different stress combinations require novel types of defense and acclimation responses ${ }^{50}$. The new protein bands (47.26 and $32.84 \mathrm{kDa})$ observed may fall under photosynthesis $(46.30 \mathrm{kDa})$, carbohydrate $(47.20 \mathrm{kDa})$ and lipid $(32.10 \mathrm{kDa})$ related proteins ${ }^{53,17}$.

In conclusion, the current elevating waterlogging and salinization situation has imposed the huge damage to agriculture and forestry, giving rise to barren and degraded areas in this constantly growing population period. In the present study, the various changes were observed in terms of morphological, physiological and biochemical 
analysis in the selected Pongamia pinnata species seedlings. It was found that the effect of salinity alone had great negative impact on biomass, leaves, chlorophyll, proline and protein content. The seedlings showed very good results under waterlogging treatment i.e. broad surface leaf area, highest photosynthetic rate and stomatal conductance, unaffected chlorophyll content and second highest proline and protein content which has impacted the highest biomass result. The presence of leaves for various analysis, highest proline and protein content, biomass and presence of two new protein bands across defensive proteins showed the tolerant behavior of seedlings under salinity + waterlogging better than salinity treatment alone. This clearly depicts the close relationship of species morphology with its physiological and biochemical condition and also shows the strong defensive response for protection and survival. Forest tree species are the most long-living organisms with the numerous tangible and intangible benefits. Hence, in order to protect the environment and livelihood and to fulfill the resource requirement of increasing population there is need of plantations of forest tree species with economically important attributes which should be suitable for such areas.

\section{Acknowledgement}

First and foremost I would like to express my deep sense of gratitude to The Director TFRI Jabalpur, Head of Office and Group Coordinator (Research) for encouraging and allowing me to conduct research work in the institute with necessary laboratory and library facilities to carry out the research work. I am thankful to my supervisor, Dr Avinash Jain, Scientist-F, Forest Ecology and Climate Change Division, for his valuable guidance and untiring support during the entire course of this work. I am also thankful to the scientists and staff of Ecology Division for helping me on every step of my research work. I am highly grateful to Jawaharlal Nehru Memorial Fund for providing me financial support in the form of scholarship to carry out the research work for two years.

\section{References}

1. Abdul-Hamid, H., Ab. Shukor, N.A., Mat, S. and Senin, A.L., Effects of waterlogging on growth and physiology of Hopea odorata Roxb, International Journal of Biology, 1 (2), 87-93 (2009)

2. Abdul-Qados, A.M.S.A., Effect of salt stress on plant growth and metabolism of bean plant Vicia faba (L.), Journal of the Saudi Society of Agricultural Sciences, 10, 7-15 (2011)

3. Arnon, D.I., Plant Physiology, 24 (1), (1949)

4. Arpiwi, N.L., Yan G., Barbour E.L. and Plummer J.A., Genetic diversity, seed traits and salinity tolerance of Millettia pinnata (L.) Panigrahi, a biodiesel tree, Genetic Resources and Crop Evolution, 60, 677-692 (2013)

5. Ashraf, M.A., Waterlogging stress in plants: A review, African Journal of Agricultural Research, 7 (13), 1976-1981 (2012)

6. Ayala-Astorga, G.I. and AlcarazMelendez, L., Salinity effects on protein content, lipid peroxidation, pigments, and proline in Paulownia imperialis (Siebold and Zaccarini) and Paulownia fortunei (Seemann and Hemsley) plant grown invitro, Electronic Journal of Biotechnology, 13, 1-15 (2010)

7. Azizi, S., Tabari, M. and Striker, G.G., Growth, physiology, and leaf ion concentration responses to long-term flooding with fresh or saline water of Populus euphratica, South African Journal of Botany, 108, 229-236 (2017)

8. Bates, L.S., Waldeen, R.P. and Teare, I.D., Plant Soil, 39 (1), 205-207 (1973) 
9. Bellard, C., Bertelsmeier, C., Leadley, P., Thuiller, W. and Courchamp, F., Impacts of climate change on the future of biodiversity, Ecology Letters, 15, 365377 (2012)

10. Bradford, M.M., Analytical Biochemistry, 72, (1976)

11. Carter, J.L., Colmer, T.D. and Veneklaas, E.J., Variable tolerance of wetland tree species to combined salinity and waterlogging is related to regulation of ion uptake and production of organic solutes, New Phytologist, 169, 123-134 (2006)

12. Daniel, J.N., Pongamia pinnata - A nitrogen fixing tree for oilseed. Forest, Farm, and Community Tree Network (FACT Net) publication, Winrock International, Arkansas, USA (1997)

13. Dat, J., Vandenabeele, S., Vranov,E., Van Montag, M., Inze, D. and Van Breusegem. F., Dual action of the active oxygen species during plant stress responses, Cellular and Molecular Life Sciences, 57, 779-795 (2000)

14. Dodd, K., Guppy, C.N., Lockwood, P.V. and Rochester, I.J., Impact of waterlogging on the nutrition of cotton (Gossypium hirsutum L.) produced in sodic soils, Crop and Pasture Science, 64, 816-824 (2013)

15. Duan, H., Ma, Y., Liu, R., Li, Q., Yang, Y. and Song, J., Effect of combined waterlogging and salinity stresses on Euhalophyte suaeda glauca, Plant Physiology and Biochemistry, 127: 231237 (2018)

16. El-Mageed, T.A.A., Mohammed, S.A., El-Samnoudi, I.M. and Ibrahirm, A.E.M., Interactive effects of soil salinity and water table depth on soil properties and sorghum (Sorghum bicolor L. Moench) production. Archives of Agriculture and Environmental Science, 3 (1), 15-24 (2018)

17. El Rabey, H.A., Al-Malki, A.L.,
Abulnaja, K.O. and Rohde, W., Proteome analysis for understanding abiotic stress (salinity and drought) tolerance in date palm (Phoenix dactylifera L.), International Journal of Genomics, 11, (2015)

18. Falakboland, Z., Understanding the physiology of combined salinity and waterlogging tolerance in barley, M.Sc. thesis, University of Tasmania, Australia, 140 (2016)

19. Falakboland, Z., Zhou, M., Zeng, F., Kiani-Pouya, A., Shabala, L. and Shabala, S., Plant ionic relation and whole plant physiological responses to waterlogging, salinity and their combination in barley, Functional Plant Biology, 44 (9), 941-953 (2017)

20. Freitas, I.A.S., Santos de, L.V.B., Silva da, A.C.F., Silva da, C.R., Silveira da, P.S. and Matos, F.S., Growth of Tectona grandis seedlings irrigated with saline water, Ciencia Florestal, 27 (3), 961-967 (2017)

21. Gibberd, M.R., Gray, J.D., Cocks, P.S. and Colmer, T.D., Waterlogging tolerance among a diverse range of Trifolium accessions is related to root porosity, lateral root formation and 'aerotropic rooting', Annals of Botany, 88, 579-589 (2001)

22. Gómez, J.M., Hernández, J.A., Jiménez, A., del Río, L.A. and Sevilla, F., Differential response of antioxidative enzymes of chloroplasts and mitochondria to long-term $\mathrm{NaCl}$ stress of pea plants. Free Radical Research, 31, S11-S18 (1999)

23. Gratani, L., Pesoli, P. and Crescente, M.F., Relationship between photosynthetic activity and chlorophyll content in an isolated Quercus Ilex L., Tree, 35 (3), 445-451 (1998)

24. Gupta, B. and Huang, B., Mechanism of salinity tolerance in plants: Physiological, biochemical, and molecular 
characterization, International Journal of Genomics, 18, (2014)

25. Handreck, K.A., Black, N.D. and Black, N., Growing media for ornamental plants and turf. UNSW Press (2002)

26. Husen, A., Growth characteristics, physiological and metabolic responses of Teak (Tectona grandis Linn. F.) clones differing in rejuvenation capacity subjected to drought stress, Silvae Genetica, 59 (2), 124-136 (2010)

27. Jackson, M.B. and Colmer, T.D., Response and adaptation by plants to flooding stress, Annals of Botany, 96 (4), 501-505 (2005)

28. Jackson, T., Trees and shrubs for saline land. Department of Environment and Primary Industries, Melbourne, Victoria (2009)

29. Kozlowski, T.T. and Pallardy, S.G., Growth control in woody plants. Academic Press, San Diego (1997)

30. Kumar, S., Studies on metal tolerance in plants, Ph.D. thesis, Savitribai Phule Pune University, Pune (2008)

31. Laemmli, U. K., Cleavage of structural proteins during the assembly of the head of bacteriophage T4, Nature, 227 (5259), 680-685 (1970)

32. Lu, S.G., Tang, C. and Rengel, Z., Combined effects of waterlogging and salinity on electrochemistry, watersoluble cations and water dispersible clay in soils with various salinity levels, Plant and Soil, 264, 231-245 (2004)

33. Martin, T.J. and Ogden, J., Experimental studies on the drought, waterlogging, and frost tolerance of Ascarina lucida Hook $\mathrm{f}$. (Chloranthaceae) seedlings, New Zealand Journal of Ecology, 29 (1), 53-59 (2005).

34. Matysik, J., Alia, A., Bhalu, B. and Mohanty, P., Molecular mechanisms of quenching of reactive oxygen species by proline under stress in plants, Current Science, 82, 525-32 (2002).

35. Mittova, V., Tal, M., Volokita, M. and
Guy, M., Salt stress induces upregulation of an efficient chloroplast antioxidant system in the salt-tolerant wild tomato species Lycopersicon pennellii but not in the cultivated species, Physiologia Plantarum, 115, 393-400 (2002).

36. Moore, B.A. and Allard, G., Abiotic disturbances and their influence on forest health. Forest Health and Biosecurity Working Papers, FAO, Rome (2011).

37. Munns, R., Comparative physiology of salt and water stress, Plant Cell Environment, 25, 239-250 (2002).

38. Munns, R., James, R.A. and Lauchli, A., Approaches to increasing the salt tolerance of wheat and other cereals, Journal of Experimental Botany, 57, 1025-1043 (2006)

39. National Remote Sensing Agency (NRSA), Wastelands Atlas of India. Hyderabad, 81 (2000)

40. Parida, A., Das 2 A.B. and Mittra, B., Effects of salt on growth, ion accumulation, photosynthesis and leaf anatomy of the mangrove, Bruguiera parviflora, Trees, 18 (2), 167-174 (2004)

41. Parvin, D. and Karmoker, J.L., Effects of waterlogging on ion accumulation and sugar, protein and proline contents in Corchorus capsular L., Bangladesh Journal of Botany, 42 (1), 55-63 (2013).

42. Pitman, M.G. and Lauchli, A., Global impact of salinity and agricultural ecosystems, 3-20: In Salinity: environment - plants - molecules, Lauchli, A. and Luttge, U. (eds.) Kluwer, Dordrecht (2002).

43. Rajaravindran, M. and Natarajan, S., Effects of salinity stress on growth and biochemical constituents of the Halophyte Sesuvium portulacastrum, International Journal of Research in Biological Science, 2 (1), 18-25 (2012).

44. Rhoades, J.D., Electrical conductivity methods for measuring and mapping soil 
salinity, 201-251: In Advances in Agronomy, Sparks, D.L. (ed.) Academic Press, San Diego, C.A. (1993)

45. Saqib, M. and Qureshi, R.H., Combined effect of salinity and hypoxia on growth, ionic composition and yield of wheat line 234-1, Pakistan Journal of Biological Science, 1 (3), 167-169 (1998)

46. Shukor, N.-N., Abdul-Hamid, H., Abdu, A. and Ismail, M.-K., Waterlogging effects on growth and physiological characteristics of Azadirachta excelsa seedlings, American Journal of Plant Physiology, 9 (3), 78-94 (2014).

47. Singh, K., Effect of soil salinity and sodicity on seedling growth and mineral composition of Pongamia pinnata and Araucaria cunninghamii, Indian Forester, 31 (6), 124-130 (1999)

48. Singh, Y.P., Minhas, P.S., Tomar, O.S. and Gupta, R.K., Salt tolerance and water use by Dalbergia sissoo during the establishment stage, Arid Soil Research and Rehabilitation, 10 (4), 379-390 (1996)

49. Su, X., Chu, Y., Li, H., Hou, Y., Zhang, B., Huang, Q., Hu, Z., Huang, R. and Tian, Y., Expression of multiple resistance genes enhances tolerance to environmental stressors in transgenic poplar (Populus $\times$ euramericana "Guariento"), PLoS ONE, 6 (9), (2011)

50. Suzuki, N., Rivero, R.M., Shulaev, V., Blumwald, E. and Mittler, R., Abiotic and biotic stress combinations, New
Phytologist, 203, 32-43 (2014).

51. Tounekti, T., Mahdhi, M., Al-Turki, T.A. and Khemira, H., Physiological responses of the halophyte Salvadora persica to the combined effect of salinity and flooding, International Journal of Agriculture and Biology, 20, 2211-2220 (2018)

52. Tyree, M.T., Vargas, G., Engelbrecht, B.M.J. and Kursar, T.A., Drought until death do us part: A case study of the desiccation-tolerance of a tropical moist forest seedling-tree, Licania platypus (Hemsl.) Fritsch, Journal of Experimental Botany, 53 (378), 22392247 (2002).

53. Vincent, D., Ergu, A., Bohlman, M.C., Tattersall, E.A.R., Tillett, R.L., Wheatley, M.D., Woolsey, R., Quilici, D.R., Joets, J., Schlauch, K., Schooley, D.A., Cushman, J.C. and Cramer, G.R., Proteomic analysis reveals differences between Vitisvinifera L. cv. Chardonnay and cv. Cabernet Sauvignon and their responses to water deficit and salinity, Journal of Experimental Botany, 58 (7), 1873-1892 (2007).

54. Wang, X., Cai, X., Xu, C., Wang, Q. and Dai, S., Drought-responsive mechanisms in plant leaves revealed by proteomics, International Journal of Molecular Science, 17, 1706 (2016)

55. Zhu, J.-K., Abiotic stress signaling and responses in plants, Cell, 167 (2), 313324 (2016).

\section{How to cite this article:}

Shephali Sachan, Sandeep Kumar, Pooja Kattiparambil and Anil kumar. 2020. Performance of Pongamia pinnata ROXB. under Waterlogging, Salinity and their Combination in Nursery Environment. Int.J.Curr.Microbiol.App.Sci. 9(07): 2619-2635. doi: https://doi.org/10.20546/ijcmas.2020.907.309 